\title{
The use of mesenchymal stromal cells in treatment of lung disorders
}

Article

Accepted Version

Kardia, E., Zakaria, N., Halim, N. S. S. A., Widera, D. and Yahaya, B. H. (2017) The use of mesenchymal stromal cells in treatment of lung disorders. Regenerative Medicine, 12 (2). pp. 2013-2016. ISSN 1746-076X doi: https://doi.org/10.2217/rme2016-0112 Available at https://centaur.reading.ac.uk/68628/

It is advisable to refer to the publisher's version if you intend to cite from the work. See Guidance on citing.

To link to this article DOI: http://dx.doi.org/10.2217/rme-2016-0112

Publisher: Future Medicine

All outputs in CentAUR are protected by Intellectual Property Rights law, including copyright law. Copyright and IPR is retained by the creators or other copyright holders. Terms and conditions for use of this material are defined in the End User Agreement.

\section{www.reading.ac.uk/centaur}

\section{CentAUR}

Central Archive at the University of Reading

Reading's research outputs online 


\section{The Use of Mesenchymal Stromal Cells in Treatment of Lung Disorders}

Running title: MSC-based therapy for lung disorders

Egi Kardia ${ }^{1}$, Norashikin Zakaria ${ }^{1}$, Nur Shuhaidatul Sarmiza Abdul Halim ${ }^{1}$, Darius Widera ${ }^{2}$ and Badrul Hisham Yahaya ${ }^{1, *}$

${ }^{1}$ Regenerative Medicine Cluster, Advanced Medical \& Dental Institute (AMDI), Universiti Sains Malaysia, Bandar Putra Bertam, 13200 Kepala Batas, Pulau Pinang, Malaysia

${ }^{2}$ Stem Cell Biology and Regenerative Medicine, School of Pharmacy, University of Reading, Whiteknights, Reading, RG6 6UB, United Kingdom

*Corresponding author

Assoc. Prof. Dr. Badrul Hisham Yahaya, Regenerative Medicine Cluster, Advanced Medical \& Dental Institute (AMDI), Universiti, Sains Malaysia, Bandar Putra Bertam, 13200 Kepala Batas, Penang, Malaysia, Tel : +604-562 2539, Fax: +604-562 2349, Email:

badrul@usm.my

\section{Emails:}

Egi Kardia: egikardia@gmail.com

Norashikin Zakaria: norashikin.zakaria@yahoo.com

Nur Shuhaidatul Sarmiza Abdul Halim: shuemiza_2003@yahoo.com

Dr. Darius Widera: d.widera@reading.ac.uk

\section{Acknowledgements:}

BHY was supported by grants from Universiti Sains Malaysia (USM) Research University Grant (1001/CIPPT/813059). The proofreading service was funded by Advanced Medical and Dental Institute (AMDI), Universiti Sains Malaysia (USM).

\section{Conflict of interest:}

The authors report no conflicts of interest. The authors alone are responsible for the content and writing of the article. 


\begin{abstract}
The therapeutic use of mesenchymal stromal cells (MSCs) represents a promising alternative clinical strategy for treating acute and chronic lung disorders. Several pre-clinical reports demonstrated that MSCs can secrete multiple paracrine factors and that their immunomodulatory properties can support endothelial and epithelial regeneration, modulate the inflammatory cascade, and protect lungs from damage. The effects of MSC transplantation into patients suffering from lung diseases should be fully evaluated through careful assessment of safety and associated risks, which is a prerequisite for translation of pre-clinical research into clinical practise. In this article we summarise the current status of pre-clinical research and review initial MSC-based clinical trials for treating lung injuries and lung disorders.
\end{abstract}

Keywords: cell-based therapy, lung disorders, mesenchymal stromal cells, mesenchymal stem cells, safety assessment

\title{
Introduction
}

The lung is a complex organ that is exposed to diverse pathogens and potentially harmful agents through the respiratory route [1]. Although the lung possesses an intrinsic capacity to regenerate itself, this endogenous repair mechanism often fails to achieve sufficient cellular turnover in pathological situations. Under normal circumstances there appears to be little need for local self-renewal, and $<1 \%$ of epithelial cells are proliferating at any given point in time $[2,3]$. Consequently, lung disorders ranging from chronic obstructive pulmonary disease (COPD) to acute lung injury (ALI)/acute respiratory distress syndrome (ARDS) represent one of the leading causes of death worldwide [4]. According to World Health Organization (WHO) statistics, COPD alone was responsible for 3.1 million deaths in 2012 [5]. Long-term investigation of the outcome of current treatment options, including lung 
transplant, revealed many associated problems and major complications in other organ systems, such as diverticulitis and perforation in the colon and rectum $[6,7]$. Thus, novel therapeutic approaches to repair, replace, restore, and regenerate a functional airway epithelium are urgently needed.

Cell-based therapy as a treatment for lung diseases is a rapidly growing field in regenerative medicine. Several pre-clinical studies reported promising results supporting the use of stem cells to treat lung diseases such as pulmonary hypertension [8, 9], ALI [10], inflammatory and immune-mediated lung conditions [1]. Mesenchymal stromal cells (MSCs) represent the most frequently used stem cell type in pre-clinical reports and clinical trials conducted so far. As of April 2016, more than 33 clinical trials utilising MSCs to treat lung disorders were registered in the database of publicly and privately supported clinical trials (search terms: 'mesenchymal stem' or 'mesenchymal stromal' cells AND 'lung'). Mechanistically, MSCs delivery can enhance the endogenous repair process by increasing the limited regenerative capacity of the lung following injury [11] and in chronic lung disorders [12] in addition to potential integration into the host tissue and functional differentiation. Moreover, the potential of adult MSCs to modulate regeneration is mediated largely through paracrine immunomodulation and reduction of inflammation [13, 14]. MSCs are also known to possess intrinsic antimicrobial properties that are mediated by secretion of antimicrobial peptides such as LL-37 [15] and beta defensin [16].

Despite their enormous clinical promise, the safety, adverse effects, and potential longterm immunological effects of MSC transplantation must be carefully evaluated to assess the feasibility of using this technique to treat lung diseases. This step is of crucial importance, especially in light of increasing MSC-related medical tourism, with considerable numbers of patients undergoing not fully proven and expensive treatments all over the world [17]. The current International Society for Stem Cell Research (ISSCR) guidelines for Stem Cell 
Research and Clinical Translation recommend that 'early phase human studies should be preceded by rigorous demonstration of safety and efficacy in pre-clinical studies' [18]. This review highlights recent advances in our understanding of the safety of MSC transplantation for the treatment of lung diseases and includes a critical assessment of complications and adverse effects reported in pre-clinical reports and clinical studies.

\section{General properties of MSCs}

MSCs are non-hematopoietic stromal cells that are present within the bone marrow and various peripheral tissues and have the ability to differentiate into a wide variety of mesenchymal cells, including adipose, bone, cartilage, tendon, muscle, and ligament cells [19, 20]. Apart from bone marrow, MSCs are present in several other adult tissue types and fluids such as adipose tissues, synovial fluid, periosteum, foetal tissues and the umbilical cord [2124]. Cultivated MSCs have a spindle-like morphology and adhere to plastic surfaces under appropriate culture conditions (e.g., in the presence of foetal calf serum). According to the International Society for Cellular Therapy (ISCT), MSCs must by definition express the cell surface antigens CD105, CD73, and CD90 and be negative for major histocompatibility complex (MHC) class II surface molecules, endothelial-(CD31), and hematopoietic markers (CD34, CD45, CD14, CD11b, CD79 $\alpha$, CD19) [19, 20, 25]. Moreover, MSCs must possess the ability to undergo osteogenic, adipogenic, and chondrogenic differentiation in vitro [20].

In principle, the therapeutic capabilities of MSCs can be explained by two distinct mechanisms: cell replacement or cell 'empowerment' [26]. Today it is widely believed that the regenerative potential of MSCs is a bystander effect resulting more from trophic support of differentiated cells and modulation of endogenous regeneration and immune suppression than a result of integration and differentiation [26-31]. Thus, the collaborative action of immune regulatory factors secreted by MSCs and endogenous cells facilitates the tissue repair process 
by reduction of apoptosis and inflammation, inhibition of scar formation, stimulation of angiogenesis, remodelling of extracellular matrix, and differentiation of tissue progenitor cells [26, 32]. MSCs themselves have low immunogenicity and possess a unique immunomodulatory capacity to affect most immune cells [33]. A typical hallmark of MSCs is the expression of functional Tumor Necrosis Factor Receptor I (TNFR1) [34] and a broad repertoire of Toll-like Receptors (TLRs) [35, 36]. After exposure to pro-inflammatory cytokines and damage-associated TLR ligands, MSCs secrete various immune regulatory factors. Notably, similar to macrophages, MSCs themselves can be polarised into MSC1 and MSC2 phenotypes after stimulation of TLR3 and TLR4 [37]. In accordance with this finding, results of recent studies provide strong evidence that the paracrine action of MSCs results in an increase of endogenous regeneration and repair, and reduction of inflammation. Whilst immunomodulation could be mainly mediated by extracellular vesicles that are released after exposure of MSCs to inflammatory mediators and damage-associated molecular patterns [13, 38]. Indeed, such extracellular vesicles have been recently proposed as a therapeutic option for the treatment of respiratory diseases including ALI and other inflammatory lung disorders [39, 40].

\section{MSCs treatment in lung disorders}

\section{Acute lung injuries}

ALI/ARDS in in vivo models is characterised by disruption of alveolar epithelial barriers [41]. The pathologic changes include an increase in endothelial permeability, infiltration of proteinaceous and fibrin fragments, and infiltration of inflammatory cells (mostly neutrophils and macrophages) into the airspaces [42, 43]. It is believed that MSC transplantation can contribute to marked reduction in pathological lung damage and alleviate the lung inflammatory response through several mechanisms that lead to down-regulation of 
pro-inflammatory mediators [44-46]. Neutrophils are considered to play a key role in the progression of both ALI and ARDS [47]. Activation and recruitment of neutrophils into the lung damages the alveolar-capillary barrier, thus resulting in oedema [48]. Xu J, Woods CR, Mora ALet al [49] reported that MSC transplantation following lipopolysaccharide (LPS) administration prevents further inflammation and injury and reduces oedema as well as the influx of neutrophils into the injured alveolar tissue. There is also evidence that MSCs can ameliorate fibrogenesis caused by bleomycin [50], radiation, and inhaled asbestos [51], and reduce oedema and mortality in a model of ALI [52].

As introduced above, one major characteristic of MSCs is their immunomodulatory action. Numerous studies have suggested that immunomodulatory factors secreted by MSCs could also be responsible for their anti-inflammatory effects in lung injuries [53-58]. It has been reported that LPS or TNF $\alpha$-induced lung injury activates transplanted MSCs to secrete prostaglandin $\mathrm{E}_{2}\left(\mathrm{PGE}_{2}\right)$, which then reprograms alveolar macrophages to secrete antiinflammatory interleukin-10 (IL-10) $[54,55]$. Notably, an increased production of IL-10 contributes subsequently to the inhibition of adhesion and transmigration of neutrophils into the alveolar wall $[53,55]$.

\section{Chronic lung injuries}

COPD and interstitial lung diseases are mostly associated with clinical chronic lung disease. Acute stages of these disorders are frequently associated with inflammatory responses, whereas chronic stages usually involve interstitial, intra-alveolar, or peri-bronchial fibrosis [59]. COPD is irreversible and often associated with expiratory airflow limitation with influx of inflammatory cells and emphysema [60]. In animal models of COPD, MSC treatment has been shown to significantly improve emphysema and lung function [61, 62]. Similar to MSC treatment for ALI/ARDS, in a COPD model, MSC transplantation down-regulated pro- 
inflammatory cytokines and increased vascular endothelial growth factor production [62]. Furthermore, it has been reported that MSCs can interact with macrophages, which then later suppress cigarette smoke-induced cyclooxygenase-2 and $\mathrm{PGE}_{2}$ production in macrophages [61]. In addition, MSCs can protect the lung from further progression of emphysema by increasing epithelial cell regeneration and reducing alveolar apoptosis [63, 64]. In asthma, administration of MSCs effectively ameliorated airway hyper-responsiveness, reduced airway wall $[65,66]$, and smooth muscle thickening [65]. MSC treatment in ovalbumin-sensitized mice also decreased levels of asthma-related inflammatory cytokines (interferon gamma (IFN$\gamma)$, IL-5, and IL-13) compared to the untreated group [67]. These results verify the effectiveness of MSCs in experimental animal studies and suggest their therapeutic potential for the treatment of airway inflammation associated with chronic lung diseases in humans such as COPD and asthma.

\section{Efficacy and safety assessment for in vivo studies of MSC treatment}

In both pre-clinical and clinical studies, a thorough and rigorous assessment of efficacy is crucial for evaluation of a potential benefit of a treatment. To assess the efficacy of MSC transplantation in treating lung disorders, vital signs, body weight, activity, food consumption, and clinical pathology such as haematology [63, 68], urine, eyes, and histopathology [68] should be observed and measured to monitor any physical changes in the experimental subject. Bronchoalveolar lavage (BAL) fluid collection is a commonly used diagnostic technique to retrieve secretions for the assessment of cellular (i.e., macrophage and leukocyte counts) and acellular components of the respiratory airways following injury [44, 69, 70]. BAL fluid specimens represent the events that occurred in the alveoli and interstitial region of the airways [71]. Pulmonary function tests should be routinely performed pre- and post- MSC delivery to identify any underlying respiratory abnormalities and to determine the condition and 
physiological responses of the recipient's lungs in order to compare pre- and post-transplant effects [72].

Pulmonary function tests are important for assessing lung function $[73,74]$. Spirometry is the most frequently used approach to measure the rate of air exhaled or inhaled [74]. However, this technique can only be applied to human patients. In experimental animal models, it is common to use whole body plethysmography to determine lung function [75-78]. In this method, the animal is unrestrained and placed in an airtight chamber after injury and treatment. This non-invasive technique determines lung volumes by measuring the changes in pressure and tidal volume during respiration in the chamber, which can be related to the animal's breathing frequency and respiratory function [74, 79, 80]. Another way to measure lung function is to use a computer-controlled and pre-programmed piston ventilator (i.e., FlexiVent) [78] that directly measures lung volumes, pressure, and flow. However this technique is invasive and requires anesthetising the animal and subjecting it to tracheostomy [81, 82].

It has been reported that intravenously administered MSCs can be trapped in the pulmonary circulation [83, 84], resulting in embolic phenomena with increased right ventricular strain and elevated pulmonary artery pressures, eventually culminating in pulmonary oedema $[85,86]$. This potential risk can be reduced by tracking the administered MSCs. Direct labelling of cells before transplant should be performed to enable the visualization of cell homing and engraftment efficacy by clinical imaging techniques [87]. Delivery route and engraftment of MSCs is discussed below in the section titled 'Biodistribution and delivery of MSCs when treating lung disorders'. Cell size is another factor that can lead to pulmonary oedema. A study comparing different MSC sizes indicated that cells with a size of 7-18 $\mu \mathrm{m}$ accumulated in the lungs after infusion, resulting in a small percentage of cells reaching the organ of interest [84]. Cell adhesion to vascular endothelium may also play a role in pulmonary cell trapping. Ruster et al. [88] demonstrated an interaction 
between MSCs and endothelial cells that involved rolling and activation of both selectindependent (P-selectin) and integrin-dependent binding (VCAM-1/VLA-4). P-selectin and VCAM-1/VLA-4 are engaged in MSC binding to vascular endothelium, thus potentially preventing MSCs from leaving the blood circulation.

According to the ISSCR guidelines, 'a stem cell-based intervention must aim at ultimately being clinically competitive with or superior to existing therapies or meet a unique therapeutic demand' [18]. Thus, a final assessment of efficacy should ultimately include a comparison with the current standard of care, at least in pre-clinical animal models.

\section{Assessment for long-term efficacy and safety of MSC treatment}

Safety assessment of any stem cell-based therapy should address likely short- and longterm risks and also consider unexpected events. The in vitro culture and expansion of stem cells harbors the intrinsic risk of culture-acquired abnormalities. Notably, in addition to pluripotent stem cells, culture-induced spontaneous transformation into a tumour-like phenotype has been reported for several adult stem cells, including neural stem cells, hippocampal progenitors, and MSCs [89-91]. For example human adipose- and bone marrow-derived MSCs has undergo spontaneous transformation when cultured for long term in vitro [89, 92]. Conversely, Bernardo ME, Zaffaroni N, Novara Fet al [93] failed to demonstrate malignant transformation in human MSCs following long-term in vitro expansion. It has been suggested that this discrepancy could be a consequence of species-specific differences. Aguilar S, Nye E, Chan Jet al [94] reported no abnormalities in human MSC cultures after prolonged cultivation, whereas murine MSCs acquired significant chromosomal abnormalities as early as after four in vitro passages. Notably, prolonged in vitro passage of murine bone marrow-derived MSCs can lead to a loss of differentiation potentiation in addition to formation of fibrosarcoma-like tumours [95]. 
The susceptibility of MSCs to malignant transformation could be explained by the two main control points in the human cell cycle (i.e., the senescence and crisis phases). The cells continue to grow and telomeres become extremely short if the senescence stage is bypassed, leading the cells to move into the crisis phase in which instability of chromosomes induces apoptosis. Despite the lower tumourigenic potential of human MSCs compared to murine MSCs, risks for tumourigenicity must be rigorously assessed (in vitro and in an appropriate animal model), and the cells used in a clinical setup should be in a low passage to minimise the risk of culture-induced transformation. In in vitro model, MSCs can be used up to passage 25 [93]. However for clinical trial, MSCs below passage 5 or less than 30 cells doubling was used [96]. In addition the US Food and Drug Administration suggested that propagation of MSCs in vitro should not exceed five weeks [97] As human MSCs have been shown to accumulate mutations with increasing cultivation time (as soon as after five weeks in culture) [92], safety assessment criteria in addition to in vivo tumourigenicity testing could be introduced (e.g., an evaluation of the karyotype and microarray-based gene expression screening for typical culture-induced mutations). In particular, expression of genes known to be associated with tumourigenic transformation of MSCs, including c-myc and Rb, should be assessed [97-99].

An additional risk of MSCs transplantation is an immune reaction of the recipient to animal-derived components of the culture medium. Notably, a clinically insignificant immune reaction against components of foetal calf serum was reported after transplantation of autologous MSCs [100]. To minimise any potential risks associated with xeno-derived medium components, use of chemically fully defined media in MSC culture and preservation is recommended [18]. One crucial factor affecting MSC expansion is the source and purity of the cells, thus the donor should be assessed for any risk of abnormalities. However, such an assessment may be challenging, as no regulations currently exist [27]. Physical factors such as 
donor age also should be taken into account, as increased donor age seems to be directly correlated with detrimental effects in terms of proliferation and multipotency of MSCs [101].

The efficacy of stem cell therapy depends on several factors, and one of the most important is the manufacturing of the cells and the ability to produce significant amounts of MSCs [27]. Tissue culture for MSC production is at high risk of microbial contamination because it requires a nutrient-rich medium. Thus, extra precautions must be taken, including proper manufacturing facilities and practices and rigorous microbiological testing [102]. Wang

S, Qu X, Zhao RC [103] suggested additional tests such as endotoxin assays, oncogenicity tests, and viability and phenotype tests; moreover cell dose and timing should be evaluated for different disease types and severities.

\section{Biodistribution and delivery of MSCs when treating lung disorders}

In general, studies of biodistribution in stem cell-based treatments are an important step towards translation of pre-clinical research into clinical trials. Usually, the success of delivery and biodistribution is assessed based on the degree of cell engraftment and the presence of transplanted cell in different tissues. However, despite beneficial effects, the engraftment of MSCs in pre-clinical models of lung diseases is generally low. Ortiz LA, Gambelli F, McBride Cet al [46] reported that systemic administration of MSCs resulted in low levels of engraftment in the normal lung of mice, although engraftment was significantly elevated in response to bleomycin-induced injury. These results are supported by a report from Gupta N, Su X, Popov B, Lee JW, Serikov V, Matthay MA [52], which states that $<5 \%$ MSC engraftment was observed 48 hours post-delivery via the intrapulmonary route into mice exposed to LPS. Interestingly, Eggenhofer E, Benseler V, Kroemer Aet al [104] have reported that one hour post-infusion of radio- and fluorescently labelled MSCs, the majority of cells can be found in the lungs, whereas after $24 \mathrm{~h}$ the cells were predominantly detected in the liver. Despite this 
low level of engraftment, several pre-clinical studies reported that MSCs improved lung regeneration and enhanced alveolar fluid clearance following lung injury [11, 46, 52, 105, 106]. Studies have shown that a large number of cells reach the lung early after injection but that they are rapidly cleared. Thus, while engraftment/retention is low, many MSCs get to the sites of injury and exert their paracrine to release extracellular vesicles to boost endogenous regeneration [104]. In addition, MSCs could exert their immunomodulatory and antiinflammatory properties through endocrine interactions with other cell types at distant sites.

Two methods are commonly used to introduce cells into the lungs: i) systemic delivery and ii) local delivery into the target tissue. Cell delivery via the intravenous route is commonly used in both pre-clinical studies $[11,44,46,50]$ and clinical trials [107-110]. The beneficial effect of the immunomodulatory properties of MSCs involves the interactions between the cells and their environment [111]. Thus, most systemic diseases treated with MSCs have used the intravenous route to deliver cells into the circulatory system $[112,113]$. Intravascular systemic delivery relies on two assumptions. First, delivered MSCs receive and respond to the injury signals produced by injured airway tissue, and those stimuli are sufficient to induce homing from blood vessels to the injury site. Second, MSCs contribute to regeneration via interactions with cells at distant sites through endocrine effects. However, intravenously administered cells must pass through the pulmonary circulation before they migrate throughout the body [114], and it is possible that intravenously administered MSCs could be trapped in the pulmonary circulation [83-86].

In contrast, intrapulmonary administration of MSCs involves direct injection of cells into the lung parenchyma $[115,116]$. This method is feasible if the therapy involves repair of lung parenchyma. This type of delivery is invasive, and it requires technical expertise to avoid injury or haemorrhage. In addition, intrapulmonary delivery may result in formation of pockets 
of cells that fail to disperse throughout the lung tissue and may affect the surrounding tissue, resulting in a local fibrotic response [115].

A further option for MSC delivery is the intratracheal route, which involves the administration of cells into the bronchial tree $[115,117-120]$. This technique requires that a small incision be made over the anterior neck in a transverse fashion [115]. Another alternative delivery method is the aerosol technique, which was initially developed as a tool to deliver medicinal compounds to the lungs more than 4000 years ago [121]. This technique is widely used to deliver pharmaceutically active compounds to the lung [122-124]. One major challenge in aerosol-based cell delivery is the choice of an appropriate aerosolisation tool that will allow efficient cell delivery without affecting cell viability. Currently there is no commercially available tool specifically designed for cell delivery. The handheld ultrasonic nebulizer (MABISmist ${ }^{\mathrm{TM}}$, Mabis Heathcare, Inc.) does not result in sufficient cell viability. However, we measured a cell viability of $80 \%$ when a custom aerosol device (MicroSprayer ${ }^{\circledR}$ Aerosolizer Model IA-1B; Penn-Century, Inc.) was applied [125]. In a pre-clinical study using rabbits as models for acute and chronic lung injuries, we found that aerosol-based cell delivery is a feasible technique to deliver cells directly into the lungs and results in a uniform distribution of aerosolised liquid containing cells (unpublished data). Based on these promising results we believe that the aerosol technique could be a valuable tool for cell-based treatment of lung disorders. Notably, in addition to stem cells, the aerosol technique represents an ideal tool for delivery of cell-derived biologicals, particularly MSC-derived extracellular vesicles.

\section{Clinical trials}

While a significant number of MSC-based clinical trials have been conducted for other implications, only a small number of trials have dealt with lung disorders. Thirty-three clinical trials that assessed the therapeutic potential of MSCs in patients with moderate to chronic lung 
disorders are registered on ClinicalTrials.gov (search terms: 'mesenchymal stem' or 'mesenchymal stromal' cells AND 'lung') (Table 1). Four of the trials have been completed and one of them (NCT00683722) demonstrated a positive effect of MSC administration. In particular, decreasing level of circulating C-reactive protein was reported in patients with moderate to severe COPD [107]. This clinical trial was initiated in 2008, involved 62 patients that suffered from moderate to severe COPD, and was completed in 2010. The patients were randomized to receive double-blinded allogeneic $1 \times 10^{8}$ MSCs/infusion (PROCHYMALTM) or a placebo-vehicle control every 4 months. Primary safety and efficacy endpoint assessments involved patients' adverse effects and reactions to the treatment, pulmonary function test results, and quality of life indicators that included a 6-minute walk test and blood and cytokine analysis. Based on these assessments, the treatment was found to be safe and beneficial in terms of improving COPD-related lung inflammation. There was no serious or clinically significant adverse effect observed following the MSC infusion. However, 33.3\% (10 out of 30 patients) in the MSC group and 25.0\% (8 out of 32 patients) in the placebo group experienced an incidence of adverse effects such as cardiac and gastrointestinal disorders [107]. Another completed clinical trial (NCT01306513) reported that treatment promoted tissue repair in emphysema. Autologous bone marrow-derived MSCs were infused into seven patients who suffered from pulmonary emphysema. The MSC treatment showed no adverse effects and lung tissue showed no fibrotic responses. An increase in CD31 expression was reported after the treatment, which indicated a response from vascular endothelial cells to repair severely affected parts of the lung [109].

In another completed clinical trial (NCT01297205), intratracheal transplantation of allogeneic MSCs (PNEUMOSTEM®) was performed in a small group of preterm infants at high risk of bronchopulmonary dysplasia [126]. The first three infants received a low dose (1 $\left.\times 10^{7} \mathrm{MSCs} / \mathrm{kg}\right)$ of cells, whereas the next six infants were given a high dose $\left(2 \times 10^{7}\right.$ 
MSCs $/ \mathrm{kg}$ ). Eighty-four days after treatment, the high dose MSC transplantation was clinically well tolerated in these infants with no adverse events, and no immediate complications related to the treatment within 6 hours after transplantation was detected. A minor adverse effect was observed subsequently in six infants. In particular, patent ductus arteriosus ligation occurred in four of the nine infants (44\%), with one case of pneumothorax $(11.1 \%)$ that was directly related to the ligation. Nevertheless, the MSC treatment resulted in a significant reduction of bronchopulmonary dysplasia severity and inflammatory cytokine levels in tracheal aspirates [126].

Completed clinical trial (NCT01385644) also revealed a positive effect of MSC transplantation in patients with lung disorders. Eight patients with a diagnosis of idiopathic pulmonary fibrosis received a dose of $1 \times 10^{6}$ (the first four patients) or $2 \times 10^{6}$ (the subsequent four patients) placenta-derived MSCs/kg via intravenous infusion. The placenta donor and MSC transplantation recipient were unrelated and HLA unmatched. A 94-99\% change in lung function was detected by comparing function before and after treatment. However, one of the four patients who received $1 \times 10^{6} \mathrm{MSCs} / \mathrm{kg}$ treatment suffered from severe abdominal pain. A CT scan confirmed that the pain was caused by a small bowel obstruction.

Clinical trials NCT01902082 [110] and NCT01775774 [127] were aimed at treating ARDS patients and showed promising results following phase 1 trials. NCT01902082 patients (total of twelve patients) received an intravenous dose of $1 \times 10^{6}$ allogeneic adipose-derived MSCs $/ \mathrm{kg}$. The first three patients in the NCT01775774 clinical trial received 1 x $10^{6} \mathrm{MSCs} / \mathrm{kg}$ via intravenous infusion and the next six patients received $5 \times 10^{6}$ and $1 \times 10^{7} \mathrm{MSCs} / \mathrm{kg}$, respectively. Both clinical trials reported that no treatment-related adverse events occurred following the treatment. Nevertheless, three patients in trial NCT01775774 subsequently developed serious adverse effects in the weeks following the infusion, although none were thought to be related to MSC administration. 
Another clinical trial (not registered on ClinicalTrials.gov) focused on ARDS attempted to correlate the clinical results with in vitro anti-inflammatory actions using the patients' own blood and BAL samples [128]. MSC administration improved respiratory dynamics with progressive decreases in pulmonary infiltrates. In parallel, a decrease was observed in multiple pulmonary and systemic markers of inflammation, including epithelial apoptosis, alveolar capillary fluid leakage, pro-inflammatory cytokines, microRNAs, and chemokines. This study proves the anti-inflammatory capacity of MSC in ARDS treatment, including suppression of T-cell responses and induction of regulatory phenotypes in T cells, monocytes, and neutrophils.

Several questions regarding the general safety of MSC application in treating lung disorders remain unanswered [129-131]. Adverse effects following MSC treatment can be difficult to predict and vary from person to person. Factors such as infections from previous or current treatment, type of cell transplant (autologous/allogeneic), use of prophylactic antibiotics, and time elapsed since transplant can influence the occurrence of these complications [132]. Thus, a thorough evaluation of the potential risks of a stem cell-based therapy must be a prerequisite before any clinical application. The use of standardised MSCderived extracellular vesicles could be superior compared to MSCs themselves. This option could also minimise problems inherent in cell delivery, including efficacy and safety following administration.

\section{Conclusions}

The clinical experience with MSC therapy is increasing and provides great hope for future treatment of lung diseases and degenerative lung conditions. Despite a limited number of successful clinical trials, a thorough evaluation of the general safety and efficacy of MSC treatment compared to that of the standard of care still needs to be conducted. In addition, open questions remain regarding the biodistribution and engraftment of MSCs versus the impact of 
paracrine factors. If paracrine factors (e.g., those embedded in extracellular vesicles) show efficacy similar to that of MSCs in pre-clinical research, clinical translation of this treatment approach could also be considered.

\section{Executive summary}

\section{General properties of MSCs}

- According to the ISCT, MSCs must by definition express the cell surface antigens CD105, CD73, and CD90 and be negative for MHC class II surface molecules, endothelial-(CD31), and hematopoietic markers (CD34, CD45, CD14, CD11b, CD79 $\alpha$, CD19).

- MSCs must possess the ability to undergo osteogenic, adipogenic, and chondrogenic differentiation in vitro.

- The regenerative potential of MSCs is a bystander effect resulting more from trophic support of differentiated cells and modulation of endogenous regeneration and immune suppression than a result of integration and differentiation.

- The paracrine action of MSCs is mainly mediated by extracellular vesicles that are released after exposure of MSCs to inflammatory mediators and damage-associated molecular patterns.

\section{MSCs treatment in lung disorders}

- In animal models of ALI, MSC transplantation prevents further inflammation, ameliorates fibrogenesis, and reduces oedema and the influx of neutrophils into the injured alveolar tissue.

- In animal models of COPD, MSC treatment has been shown to significantly improve emphysema and lung function, whereas in asthma, administration of MSCs was effective at ameliorating airway hyper-responsiveness. 


\section{Efficacy and safety assessment for in vivo study}

- The efficacy of MSC transplantation is assessed by observing vital signs, body weight, activity, food consumption, and clinical pathology (e.g., haematology, urine, eyes, histopathology, and BAL fluid collection).

- Pulmonary function tests should be routinely performed pre- and post- MSC delivery. In experimental animal models, it is common to use whole body plethysmography and a computer-controlled and pre-programmed piston ventilator to evaluate lung function.

- There have been reports that intravenously administered MSCs can be trapped in the pulmonary circulation. Cell size is also a factor that can lead to this condition, and this potential risk can be reduced by tracking/labelling the administered MSCs.

\section{Assessment for long-term efficacy and safety treatment}

- Spontaneous transformation of MSCs into a tumour-like phenotype following longterm in vitro culture is possible, but results of different studies vary. This discrepancy could be a consequence of species-specific differences, including differences in senescence and the crisis phase of the cells.

- An evaluation of the karyotype and microarray-based gene expression screening for typical culture-induced mutations could be introduced as safety assessment criteria in addition to in vivo tumourigenicity testing.

- To minimise any potential risks associated with xeno-derived medium components, use of chemically fully defined media in MSC culture and preservation is recommended.

- Tissue culture for MSC production has a high risk of microbial contaminations because it requires a nutrient-rich medium. Thus, extra precautions must be taken, including proper manufacturing facilities and practices and rigorous microbiological testing.

\section{Biodistribution and delivery of MSCs in lung disorders}


- The engraftment of MSCs in pre-clinical models of lung diseases is generally low. Despite this low level of engraftment, several pre-clinical studies reported that MSCs improve lung repair and regeneration.

- In a pre-clinical study in rabbits as models for acute and chronic lung injuries, we found that aerosol-based cell delivery is a feasible technique to deliver cells directly into the lungs and results in a uniform distribution of aerosolised liquid containing cells (unpublished data).

\section{Clinical trials}

- There are thirty-three clinical trials registered on ClinicalTrials.gov (search terms: 'mesenchymal stem' or 'mesenchymal stromal' cells AND 'lung') that assessed the therapeutic potential of MSCs in patients with moderate to chronic lung disorders.

- Four of the trials have been completed and have demonstrated a positive effect of MSC administration.

\section{Conclusions}

- MSC therapy is increasing and provides great hope for future treatment of lung diseases and degenerative lung conditions.

- Despite a limited number of successful clinical trials, a thorough evaluation of the general safety and efficacy of MSC treatment compared to that of the standard of care is needed.

- An open question remains regarding the role of MSC biodistribution and cell engraftment versus the impact of paracrine factors on mediating MSC treatment. If paracrine factors (e.g., those embedded in extracellular vesicles) show efficacy similar to that of MSCs in pre-clinical research, a clinical translation of this approach could also be considered. 


\section{References}

1. Lama VN, Smith L, Badri L et al. Evidence for tissue-resident mesenchymal stem cells in human adult lung from studies of transplanted allografts. J. Clin. Invest. 117(4), 989996 (2007).

2. Boers JE, Den Brok JL, Koudstaal J, Arends JW, Thunnissen FB. Number and proliferation of neuroendocrine cells in normal human airway epithelium. Am. J. Respir. Crit. Care. Med. 154(3 Pt 1), 758-763 (1996).

3. Demoly P, Simony-Lafontaine J, Chanez P et al. Cell proliferation in the bronchial mucosa of asthmatics and chronic bronchitics. Am. J. Respir. Crit. Care. Med. 150(1), 214-217 (1994).

4. Sueblinvong V, Weiss DJ. Stem cells and cell therapy approaches in lung biology and diseases. Transl. Res. 156(3), 188-205 (2010).

5. Organization WH. World Health Organization Fact Sheet COPD. 2016(05/11/2016), (2015).

6. Trulock EP, Christie JD, Edwards LB et al. Registry of the International Society for Heart and Lung Transplantation: twenty-fourth official adult lung and heart-lung transplantation report-2007. J. Heart. Lung. Transplant. 26(8), 782-795 (2007).

7. Goldberg HJ, Hertz MI, Ricciardi R, Madoff RD, Baxter NN, Bullard KM. Colon and rectal complications after heart and lung transplantation. J. Am. Coll. Surg. 202(1), 5561 (2006).

8. Wang XX, Zhang FR, Shang YP et al. Transplantation of autologous endothelial progenitor cells may be beneficial in patients with idiopathic pulmonary arterial hypertension: a pilot randomized controlled trial. J. Am. Coll. Cardiol. 49(14), 15661571 (2007).

9. Zhu JH, Wang XX, Zhang FR et al. Safety and efficacy of autologous endothelial progenitor cells transplantation in children with idiopathic pulmonary arterial hypertension: open-label pilot study. Pediatr. Transplant. 12(6), 650-655 (2008).

10. Matthay MA, Thompson BT, Read EJ et al. Therapeutic potential of mesenchymal stem cells for severe acute lung injury. Chest. 138(4), 965-972 (2010).

11. Curley GF, Hayes M, Ansari B et al. Mesenchymal stem cells enhance recovery and repair following ventilator-induced lung injury in the rat. Thorax. 67(6), 496-501 (2012).

12. Van Haaften T, Byrne R, Bonnet $\mathrm{S}$ et al. Airway delivery of mesenchymal stem cells prevents arrested alveolar growth in neonatal lung injury in rats. Am. J. Respir. Crit. Care Med. 180(11), 1131-1142 (2009).

13. Zeuner MT, Patel K, Denecke B, Giebel B, Widera D. Paracrine effects of TLR4polarised mesenchymal stromal cells are mediated by extracellular vesicles. J. Transl. Med. 1434 (2016).

14. Konala VB, Mamidi MK, Bhonde R, Das AK, Pochampally R, Pal R. The current landscape of the mesenchymal stromal cell secretome: A new paradigm for cell-free regeneration. Cytotherapy. 18(1), 13-24 (2016). 
15. Krasnodembskaya A, Song Y, Fang X et al. Antibacterial effect of human mesenchymal stem cells is mediated in part from secretion of the antimicrobial peptide LL-37. Stem Cells. 28(12), 2229-2238 (2010).

16. Sung DK, Chang YS, Sung SI, Yoo HS, Ahn SY, Park WS. Antibacterial effect of mesenchymal stem cells against Escherichia coli is mediated by secretion of betadefensin- 2 via toll- like receptor 4 signalling. Cell Microbiol. 18(3), 424-436 (2016).

17. Prockop DJ, Prockop SE, Bertoncello I. Are clinical trials with mesenchymal stem/progenitor cells too far ahead of the science? Lessons from experimental hematology. Stem Cells. 32(12), 3055-3061 (2014).

18. Daley GQ, Hyun I, Apperley JF et al. Setting Global Standards for Stem Cell Research and Clinical Translation: The 2016 ISSCR Guidelines. Stem Cell Reports. 6(6), 787-97 (2016).

* An excellect review on the standard guidlines for the use of stem cells in research and clinical applications.

19. Pittenger MF, Mackay AM, Beck SC et al. Multilineage potential of adult human mesenchymal stem cells. Science. 284(5411), 143-147 (1999).

20. Dominici M, Le Blanc K, Mueller I et al. Minimal criteria for defining multipotent mesenchymal stromal cells. The International Society for Cellular Therapy position statement. Cytotherapy. 8(4), 315-317 (2006).

* This position paper provides the standard minimal criteria used in defining the multipotent human MSCs

21. Bieback K, Kern S, Klüter H, Eichler H. Critical parameters for the isolation of mesenchymal stem cells from umbilical cord blood. Stem Cells. 22(4), 625-634 (2004).

22. De Bari C, Dell'accio F, Luyten FP. Human periosteum- derived cells maintain phenotypic stability and chondrogenic potential throughout expansion regardless of donor age. Arthritis \& Rheumatism. 44(1), 85-95 (2001).

23. Scherjon SA, Kleijburg-Van Der Keur C, Noort WA et al. Amniotic fluid as a novel source of mesenchymal stem cells for therapeutic transplantation. Blood. 102(4), 15481549 (2003).

24. Zuk PA, Zhu M, Ashjian P et al. Human adipose tissue is a source of multipotent stem cells. Mol. Biol. Cell. 13(12), 4279-4295 (2002).

25. Majumdar MK, Keane-Moore M, Buyaner D et al. Characterization and functionality of cell surface molecules on human mesenchymal stem cells. J. Biomed. Sci. 10(2), 228-241 (2003).

26. Wang Y, Chen X, Cao W, Shi Y. Plasticity of mesenchymal stem cells in immunomodulation: pathological and therapeutic implications. Nat. Immunol. 15(11), 1009-1016 (2014).

27. Sharma RR, Pollock K, Hubel A, Mckenna D. Mesenchymal stem or stromal cells: a review of clinical applications and manufacturing practices. Transfusion. 54(5), 14181437 (2014).

* A very good review that gives an overview of the current clinical status of MSC therapy focusing on immunomodulatory,regenerative and tissue repair applications of MSCs. 
28. Prockop DJ. "Stemness" does not explain the repair of many tissues by mesenchymal stem/multipotent stromal cells (MSCs). Clin. Pharmacol. Ther. 82(3), 241-243 (2007).

29. Bieback K, Wuchter P, Besser D et al. Mesenchymal stromal cells (MSCs): science and f(r)iction. J. Mol. Med. (Berl). 90(7), 773-782 (2012).

30. Maumus M, Jorgensen C, Noel D. Mesenchymal stem cells in regenerative medicine applied to rheumatic diseases: role of secretome and exosomes. Biochimie. 95(12), 2229-2234 (2013).

31. Kyurkchiev D, Bochev I, Ivanova-Todorova E et al. Secretion of immunoregulatory cytokines by mesenchymal stem cells. World J. Stem Cells. 6(5), 552-570 (2014).

32. Caplan AI, Dennis JE. Mesenchymal stem cells as trophic mediators. J. Cell Biochem. 98(5), 1076-1084 (2006).

33. Atala A, Lanza R, Thomson JA, Nerem R. Principles of regenerative medicine. New York: Academic Press, (2010).

34. Lee RH, Yoon N, Reneau JC, Prockop DJ. Preactivation of human MSCs with TNFalpha enhances tumor-suppressive activity. Cell Stem Cell. 11(6), 825-835 (2012).

35. Gazdic M, Volarevic V, Arsenijevic N, Stojkovic M. Mesenchymal stem cells: a friend or foe in immune-mediated diseases. Stem Cell Rev. 11(2), 280-287 (2015).

36. Zeuner M, Bieback K, Widera D. Controversial Role of Toll-like Receptor 4 in Adult Stem Cells. Stem Cell Rev. 11(4), 621-634 (2015).

37. Waterman RS, Tomchuck SL, Henkle SL, Betancourt AM. A new mesenchymal stem cell (MSC) paradigm: polarization into a pro-inflammatory MSC1 or an Immunosuppressive MSC2 phenotype. PLoS One. 5(4), e10088 (2010).

38. Ti D, Hao H, Tong $\mathrm{C}$ et al. LPS-preconditioned mesenchymal stromal cells modify macrophage polarization for resolution of chronic inflammation via exosome-shuttled let-7b. J. Transl. Med. 13(1), 308 (2015).

39. Abreu SC, Weiss DJ, Rocco PR. Extracellular vesicles derived from mesenchymal stromal cells: a therapeutic option in respiratory diseases? Stem Cell Res. Ther. 7(1), 53 (2016).

40. Monsel A, Zhu YG, Gudapati V, Lim H, Lee JW. Mesenchymal stem cell derived secretome and extracellular vesicles for acute lung injury and other inflammatory lung diseases. Expert Opin. Biol. Ther. 16(7), 859-71 (2016).

41. Johnson ER, Matthay MA. Acute lung injury: epidemiology, pathogenesis, and treatment. J. Aerosol Med. Pulm. Drug Deliv. 23(4), 243-252 (2010).

42. Matute-Bello G, Downey G, Moore BB et al. An official American Thoracic Society workshop report: features and measurements of experimental acute lung injury in animals. Am. J. Respir. Cell Mol. Biol. 44(5), 725-738 (2011).

43. Martin TR, Matute-Bello G. Experimental models and emerging hypotheses for acute lung injury. Crit. Care Clin. 27(3), 735-752 (2011).

44. Devaney J, Horie S, Masterson C et al. Human mesenchymal stromal cells decrease the severity of acute lung injury induced by E. coli in the rat. Thorax. 70(7), 625-635 (2015).

45. Rojas $\mathrm{M}, \mathrm{Xu} \mathrm{J}$, Woods $\mathrm{CR}$ et al. Bone marrow-derived mesenchymal stem cells in repair of the injured lung. Am. J. Respir. Cell Mol. Biol. 33(2), 145-152 (2005). 
46. Ortiz LA, Gambelli F, Mcbride $\mathrm{C}$ et al. Mesenchymal stem cell engraftment in lung is enhanced in response to bleomycin exposure and ameliorates its fibrotic effects. Proc. Natl. Acad. Sci. U S A. 100(14), 8407-8411 (2003).

47. Abraham E. Neutrophils and acute lung injury. Crit. Care Med. 31(4 Suppl), S195-199 (2003).

48. Grommes J, Soehnlein O. Contribution of neutrophils to acute lung injury. Mol. Med. 17(3-4), 293-307 (2011).

49. Xu J, Woods CR, Mora AL et al. Prevention of endotoxin-induced systemic response by bone marrow-derived mesenchymal stem cells in mice. Am. J. Physiol. Lung Cell Mol. Physiol. 293(1), L131-141 (2007).

50. Ortiz LA, Dutreil M, Fattman C et al. Interleukin 1 receptor antagonist mediates the antiinflammatory and antifibrotic effect of mesenchymal stem cells during lung injury. Proc. Natl. Acad. Sci. U S A. 104(26), 11002-11007 (2007).

51. Levis J, Loi R, Butnor KJ et al. Decreased asbestos-induced lung inflammation and fibrosis after radiation and bone marrow transplant. Am. J. Respir. Cell Mol. Biol. 38(1), 16-25 (2008).

52. Gupta N, Su X, Popov B, Lee JW, Serikov V, Matthay MA. Intrapulmonary delivery of bone marrow-derived mesenchymal stem cells improves survival and attenuates endotoxin-induced acute lung injury in mice. J. Immunol. 179(3), 1855-1863 (2007).

53. Ajuebor MN, Das AM, Virag L, Flower RJ, Szabo C, Perretti M. Role of resident peritoneal macrophages and mast cells in chemokine production and neutrophil migration in acute inflammation: evidence for an inhibitory loop involving endogenous IL-10. J. Immunol. 162(3), 1685-1691 (1999).

54. Nauta AJ, Fibbe WE. Immunomodulatory properties of mesenchymal stromal cells. Blood. 110(10), 3499-3506 (2007).

55. Lee JW, Fang X, Krasnodembskaya A, Howard JP, Matthay MA. Concise review: Mesenchymal stem cells for acute lung injury: role of paracrine soluble factors. Stem Cells. 29(6), 913-919 (2011).

** This review provides useful information on the recent studies that support the potential therapeutic use of MSCs in ALI/ARDS.

56. Yagi H, Soto-Gutierrez A, Kitagawa Y, Tilles AW, Tompkins RG, Yarmush ML. Bone marrow mesenchymal stromal cells attenuate organ injury induced by LPS and burn. Cell Transplant. 19(6), 823-830 (2010).

57. Guan XJ, Song L, Han FF et al. Mesenchymal stem cells protect cigarette smokedamaged lung and pulmonary function partly via VEGF-VEGF receptors. J. Cell. Biochem. 114(2), 323-335 (2013).

58. Spaggiari GM, Abdelrazik H, Becchetti F, Moretta L. MSCs inhibit monocyte-derived DC maturation and function by selectively interfering with the generation of immature DCs: central role of MSC-derived prostaglandin E2. Blood. 113(26), 6576-6583 (2009).

59. Mora AL, Rojas M. Adult stem cells for chronic lung diseases. Respirology. 18(7), 1041-1046 (2013). 
60. Rabe KF, Hurd S, Anzueto A et al. Global strategy for the diagnosis, management, and prevention of chronic obstructive pulmonary disease: GOLD executive summary. Am. J. Respir. Crit. Care Med. 176(6), 532-555 (2007).

61. Gu W, Song L, Li XM, Wang D, Guo XJ, Xu WG. Mesenchymal stem cells alleviate airway inflammation and emphysema in COPD through down-regulation of cyclooxygenase-2 via p38 and ERK MAPK pathways. Sci. Rep. 5, 8733 (2015).

62. Guan XJ, Song L, Han FF et al. Mesenchymal stem cells protect cigarette smokedamaged lung and pulmonary function partly via VEGF-VEGF receptors. J. Cell. Biochem. 114(2), 323-335 (2013).

63. Ingenito EP, Tsai L, Murthy S, Tyagi S, Mazan M, Hoffman A. Autologous lungderived mesenchymal stem cell transplantation in experimental emphysema. Cell Transplant. 21(1), 175-189 (2012).

64. Zhen G, Liu H, Gu N, Zhang H, Xu Y, Zhang Z. Mesenchymal stem cells transplantation protects against rat pulmonary emphysema. Front. Biosci. 13, 34153422 (2008).

65. Firinci F, Karaman M, Baran Y et al. Mesenchymal stem cells ameliorate the histopathological changes in a murine model of chronic asthma. Int. Immunopharmacol. 11(8), 1120-1126 (2011).

66. Trzil JE, Masseau I, Webb TL et al. Intravenous adipose-derived mesenchymal stem cell therapy for the treatment of feline asthma: a pilot study. J. Feline Med. Surg. 18(12), 981-990 (2015).

67. Bonfield TL, Koloze M, Lennon DP, Zuchowski B, Yang SE, Caplan AI. Human mesenchymal stem cells suppress chronic airway inflammation in the murine ovalbumin asthma model. Am. J. Physiol. Lung Cell Mol. Physiol. 299(6), L760-770 (2010).

68. Ra JC, Shin IS, Kim SH et al. Safety of intravenous infusion of human adipose tissuederived mesenchymal stem cells in animals and humans. Stem Cells Dev. 20(8), 12971308 (2011).

69. Urbanek K, De Angelis A, Spaziano G et al. Intratracheal Administration of Mesenchymal Stem Cells Modulates Tachykinin System, Suppresses Airway Remodeling and Reduces Airway Hyperresponsiveness in an Animal Model. PLoS One. 11(7), e0158746 (2016).

70. Aslam M, Baveja R, Liang OD et al. Bone marrow stromal cells attenuate lung injury in a murine model of neonatal chronic lung disease. Am. J. Respir. Crit. Care Med. 180(11), 1122-1130 (2009).

71. Hawkins EC, Denicola DB, Kuehn NF. Bronchoalveolar lavage in the evaluation of pulmonary disease in the dog and cat. State of the art. J. Vet. Intern. Med. 4(5), 267274 (1990).

72. Parimon T, Madtes DK, Au DH, Clark JG, Chien JW. Pretransplant lung function, respiratory failure, and mortality after stem cell transplantation. Am. J. Respir. Crit. Care Med. 172(3), 384-390 (2005).

* Overview about pretransplant lung function, the risk of development of early respiratory failure and mortality. 
73. Ranu H, Wilde M, Madden B. Pulmonary function tests. Ulster Med. J. 80(2), 84-90 (2011).

74. Chien JW, Madtes DK, Clark JG. Pulmonary function testing prior to hematopoietic stem cell transplantation. Bone Marrow Transplant. 35(5), 429-435 (2005).

75. Lee SH, Jang AS, Kwon JH, Park SK, Won JH, Park CS. Mesenchymal stem cell transfer suppresses airway remodeling in a toluene diisocyanate-induced murine asthma model. Allergy Asthma Immunol. Res. 3(3), 205-211 (2011).

76. Jungebluth $\mathrm{P}$, Luedde M, Ferrer E et al. Mesenchymal stem cells restore lung function by recruiting resident and nonresident proteins. Cell Transplant. 20(10), 1561-1574 (2011).

77. Yang KY, Shih HC, How CK et al. IV delivery of induced pluripotent stem cells attenuates endotoxin-induced acute lung injury in mice. Chest. 140(5), 1243-1253 (2011).

78. Tibboel J, Keijzer R, Reiss I, De Jongste JC, Post M. Intravenous and intratracheal mesenchymal stromal cell injection in a mouse model of pulmonary emphysema. COPD. 11(3), 310-318 (2014).

79. Rojas M, Woods CR, Mora AL, Xu J, Brigham KL. Endotoxin-induced lung injury in mice: structural, functional, and biochemical responses. Am. J. Physiol. Lung Cell. Mol. Physiol. 288(2), L333-341 (2005).

80. Kips JC, Anderson GP, Fredberg JJ et al. Murine models of asthma. Eur. Respir. J. 22(2), 374-382 (2003).

81. De Vleeschauwer SI, Rinaldi M, De Vooght V et al. Repeated invasive lung function measurements in intubated mice: an approach for longitudinal lung research. Lab. Animals. 45(2), 81-89 (2011).

82. Vanoirbeek JA, Rinaldi M, De Vooght V et al. Noninvasive and invasive pulmonary function in mouse models of obstructive and restrictive respiratory diseases. Am. J. Respir. Cell Mol. Biol. 42(1), 96-104 (2010).

83. Schrepfer S, Deuse T, Reichenspurner H, Fischbein MP, Robbins RC, Pelletier MP. Stem cell transplantation: the lung barrier. Transplant. Proc. 39(2), 573-576 (2007).

84. Fischer UM, Harting MT, Jimenez F et al. Pulmonary passage is a major obstacle for intravenous stem cell delivery: the pulmonary first-pass effect. Stem Cells Dev. 18(5), 683-692 (2009).

* A good research paper assessing the variables that may affect the pulmonary firstpass effect, which is one of the obstacles in intravenous (IV) stem cell delivery for regenerative tissue therapy.

85. Lalu MM, Mcintyre L, Pugliese C et al. Safety of Cell Therapy with Mesenchymal Stromal Cells (SafeCell): A Systematic Review and Meta-Analysis of Clinical Trials. PLoS One. 7(10), e47559 (2012).

86. Lee JW, Rocco PR, Pelosi P. Mesenchymal stem cell therapy for acute respiratory distress syndrome: a light at the end of the tunnel? Anesthesiology. 122(2), 238-240 (2015).

87. Fu Y, Kraitchman DL. Stem cell labeling for noninvasive delivery and tracking in cardiovascular regenerative therapy. Expert Rev. Cardiovasc. Ther. 8(8), 1149-1160 (2010). 
88. Ruster B, Gottig S, Ludwig RJ et al. Mesenchymal stem cells display coordinated rolling and adhesion behavior on endothelial cells. Blood. 108(12), 3938-3944 (2006).

89. Rosland GV, Svendsen A, Torsvik A et al. Long-term cultures of bone marrow-derived human mesenchymal stem cells frequently undergo spontaneous malignant transformation. Cancer Res. 69(13), 5331-5339 (2009).

90. Nguyen TD, Widera D, Greiner J et al. Prolonged cultivation of hippocampal neural precursor cells shifts their differentiation potential and selects for aneuploid cells. Biol. Chem. 394(12), 1623-1636 (2013).

91. Kaus A, Widera D, Kassmer S et al. Neural stem cells adopt tumorigenic properties by constitutively activated NF-kappaB and subsequent VEGF up-regulation. Stem Cells Dev. 19(7), 999-1015 (2010).

92. Rubio D, Garcia-Castro J, Martin MC et al. Spontaneous human adult stem cell transformation. Cancer Res. 65(8), 3035-3039 (2005).

93. Bernardo ME, Zaffaroni N, Novara F et al. Human bone marrow-derived mesenchymal stem cells do not undergo transformation after long-term in vitro culture and do not exhibit telomere maintenance mechanisms. Cancer Res. 67(19), 9142-9149 (2007).

94. Aguilar S, Nye E, Chan J et al. Murine but Not Human Mesenchymal Stem Cells Generate Osteosarcoma- Like Lesions in the Lung. Stem Cells. 25(6), 1586-1594 (2007).

95. Miura M, Miura Y, Padilla-Nash HM et al. Accumulated chromosomal instability in murine bone marrow mesenchymal stem cells leads to malignant transformation. Stem Cells. 24(4), 1095-1103 (2006).

96. Fink DW, Jr. FDA regulation of stem cell-based products. Science. 324(5935), 16621663 (2009).

97. Rubio D, Garcia S, Paz MF et al. Molecular characterization of spontaneous mesenchymal stem cell transformation. PLoS One. 3(1), e1398 (2008).

98. Pan Q, Fouraschen SM, De Ruiter PE et al. Detection of spontaneous tumorigenic transformation during culture expansion of human mesenchymal stromal cells. Exp. Biol. Med. (Maywood). 239(1), 105-115 (2014).

99. Wang JY, Wu PQ, Chen PC, Lee CW, Chen WM, Hung SC. Generation of Osteosarcomas From a Combination of Rb Silencing and c-Myc Overexpression in Human Mesenchymal Stem Cells. Stem Cells Transl. Med. 5(12) (2016).

100. Sundin M, Ringden O, Sundberg B, Nava S, Gotherstrom C, Le Blanc K. No alloantibodies against mesenchymal stromal cells, but presence of anti-fetal calf serum antibodies, after transplantation in allogeneic hematopoietic stem cell recipients. Haematologica. 92(9), 1208-1215 (2007).

101. Stolzing A, Jones E, Mcgonagle D, Scutt A. Age-related changes in human bone marrow-derived mesenchymal stem cells: Consequences for cell therapies. Mech. Ageing Dev. 129(3), 163-173 (2008).

102. Rohde E, Schallmoser K, Bartmann C, Reinisch A, Strunk D. GMP-Compliant Propagation of Human Multipotent Mesenchymal Stromal Cells. In: Pharmaceutical Sciences Encyclopedia, (Ed.^(Eds). John Wiley \& Sons, Inc. (2010).

103. Wang S, Qu X, Zhao RC. Clinical applications of mesenchymal stem cells. J. Hematol. Oncol. 5, 19 (2012). 
104. Eggenhofer E, Benseler V, Kroemer A et al. Mesenchymal stem cells are short-lived and do not migrate beyond the lungs after intravenous infusion. Front. Immunology. 3, 297 (2012).

* This study provides evidence that MSC are short-lived after i.v. infusion and that the viable cells are unable to pass through the lungs.

105. Hayes M, Masterson C, Devaney J et al. Therapeutic Efficacy of Human Mesenchymal Stromal Cells in the Repair of Established Ventilator-induced Lung Injury in the Rat. Anesthesiology. 122(2), 363-373 (2015).

106. Mei SH, Haitsma JJ, Dos Santos CC et al. Mesenchymal stem cells reduce inflammation while enhancing bacterial clearance and improving survival in sepsis. Am. J. Respir. Crit Care Med. 182(8), 1047-1057 (2010).

107. Weiss DJ, Casaburi R, Flannery R, Leroux-Williams M, Tashkin DP. A placebocontrolled, randomized trial of mesenchymal stem cells in COPD. Chest. 143(6), 15901598 (2013).

108. Lazarus HM, Haynesworth SE, Gerson SL, Rosenthal NS, Caplan AI. Ex vivo expansion and subsequent infusion of human bone marrow-derived stromal progenitor cells (mesenchymal progenitor cells): implications for therapeutic use. Bone Marrow Transplant. 16(4), 557-564 (1995).

109. Stolk J, Broekman W, Mauad T et al. A phase I study for intravenous autologous mesenchymal stromal cell administration to patients with severe emphysema. QJM. 109(5), 331-336 (2016).

110. Zheng G, Huang L, Tong $\mathrm{H}$ et al. Treatment of acute respiratory distress syndrome with allogeneic adipose-derived mesenchymal stem cells: a randomized, placebo-controlled pilot study. Respir. Res. 15, 39 (2014).

111. Peired AJ, Sisti A, Romagnani P. Mesenchymal stem cell-based therapy for kidney disease: a review of clinical evidence. Stem Cells Int. 4798639 (2016).

112. Liang J, Zhang H, Hua B et al. Allogenic mesenchymal stem cells transplantation in refractory systemic lupus erythematosus: a pilot clinical study. Ann. Rheum. Dis. 69(8), 1423-1429 (2010).

113. Carrion F, Nova E, Ruiz C et al. Autologous mesenchymal stem cell treatment increased $\mathrm{T}$ regulatory cells with no effect on disease activity in two systemic lupus erythematosus patients. Lupus. 19(3), 317-322 (2010).

114. Kean TJ, Lin P, Caplan AI, Dennis JE. MSCs: Delivery Routes and Engraftment, CellTargeting Strategies, and Immune Modulation. Stem Cells Int. 732742 (2013).

115. Crisanti MC, Koutzaki SH, Mondrinos MJ, Lelkes PI, Finck CM. Novel methods for delivery of cell-based therapies. J. Surg. Research. 146(1), 3-10 (2008).

116. Gupta N, Su X, Popov B, Lee JW, Serikov V, Matthay MA. Intrapulmonary delivery of bone marrow-derived mesenchymal stem cells improves survival and attenuates endotoxin-induced acute lung injury in mice. J. Immunol. 179(3), 1855-1863 (2007).

117. Baber SR, Deng W, Master RG et al. Intratracheal mesenchymal stem cell administration attenuates monocrotaline-induced pulmonary hypertension and endothelial dysfunction. Am. J. Physiol. Heart Circ. Physiol. 292(2), H1120-H1128 (2007). 
118. Leblond A-L, Naud P, Forest V et al. Developing cell therapy techniques for respiratory disease: intratracheal delivery of genetically engineered stem cells in a murine model of airway injury. Human Gene Ther. 20(11), 1329-1343 (2009).

119. Bragonzi A, Dina G, Villa A et al. Biodistribution and transgene expression with nonviral cationic vector/DNA complexes in the lungs. Gene Ther. 7(20), 1753-1760 (2000).

120. Wong AP, Dutly AE, Sacher A et al. Targeted cell replacement with bone marrow cells for airway epithelial regeneration. Am. J. Physiol. Lung Cell. Mol. Physiol. 293(3), L740-L752 (2007).

121. Anderson PJ. History of aerosol therapy: liquid nebulization to MDIs to DPIs. Respir. Care. 50(9), 1139-1150 (2005).

122. Garcia A, Mack P, Williams S et al. Microfabricated engineered particle systems for respiratory drug delivery and other pharmaceutical applications. J. Drug Deliv. 2012 941243 (2012).

123. Walther FJ, Hernandez-Juviel JM, Waring AJ. Aerosol delivery of synthetic lung surfactant. PeerJ. 2 e403 (2014).

124. Lombry C, Bosquillon C, Preat V, Vanbever R. Confocal imaging of rat lungs following intratracheal delivery of dry powders or solutions of fluorescent probes. J. Control Release. 83(3), 331-341 (2002).

125. Kardia E, Yusoff N, Zakaria Z, Yahaya B. Aerosol-Based Delivery of Fibroblast Cells for Treatment of Lung Diseases. J. Aerosol Med. Pulm. Drug Deliv. 27(1), 30-34 (2014).

126. Chang YS, Ahn SY, Yoo HS et al. Mesenchymal stem cells for bronchopulmonary dysplasia: phase 1 dose-escalation clinical trial. J. Pediatr. 164(5), 966-972 (2014).

127. Wilson JG, Liu KD, Zhuo $\mathrm{H}$ et al. Mesenchymal stem (stromal) cells for treatment of ARDS: a phase 1 clinical trial. Lancet Respir. Med. 3(1), 24-32 (2015).

128. Simonson OE, Mougiakakos D, Heldring N et al. In Vivo Effects of Mesenchymal Stromal Cells in Two Patients With Severe Acute Respiratory Distress Syndrome. Stem Cells Transl. Med. 4(10), 1199-1213 (2015).

129. Beckermann B, Kallifatidis G, Groth A et al. VEGF expression by mesenchymal stem cells contributes to angiogenesis in pancreatic carcinoma. Br. J Cancer. 99(4), 622-631 (2008).

130. Herberts CA, Kwa M, Hermsen H. Risk factors in the development of stem cell therapy. J. Transl. Med. 9(1), 29-42 (2011).

** Review on the potential risks of stem cell therapy.

131. Jeong J-O, Han JW, Kim J-M et al. Malignant tumor formation after transplantation of short-term cultured bone marrow mesenchymal stem cells in experimental myocardial infarction and diabetic neuropathy. Circ. Res. 108(11), 1340-1347 (2011).

132. Afessa B, Litzow MR, Tefferi A. Bronchiolitis obliterans and other late onset noninfectious pulmonary complications in hematopoietic stem cell transplantation. Bone Marrow Transplant. 28(5), 425-434 (2001). 
Table 1 Registered clinical trials of MSCs treatment for acute to chronic lung diseases (from

ClinicalTrials.gov, last updated 04/05/16).

\begin{tabular}{|c|c|c|c|c|c|}
\hline ID & Phase & Donor cells & Delivery route & Conditions & Year \\
\hline $\begin{array}{c}\text { NCT00683722 } \\
{[107]} \\
\end{array}$ & Completed & $\begin{array}{l}\text { PROCHYMAL } \\
\text { adult stem cells) }\end{array}$ & $\begin{array}{c}\text { Intravenous } \\
\text { infusion }\end{array}$ & COPD & 2008 \\
\hline $\begin{array}{c}\text { NCT01306513 } \\
{[109]} \\
\end{array}$ & Completed & Bone marrow-derived MSCs & $\begin{array}{c}\text { Intravenous } \\
\text { infusion }\end{array}$ & Pulmonary emphysema & 2010 \\
\hline NCT01385644 & Completed & Placenta-derived MSCs & $\begin{array}{l}\text { Intravenous } \\
\text { infusion }\end{array}$ & Idiopathic pulmonary fibrosis & 2010 \\
\hline NCT01207869 & 1 & Umbilical cord-derived MSCs & $\begin{array}{l}\text { Through a catheter } \\
\text { inserted into the } \\
\text { endotracheal tube }\end{array}$ & Bronchopulmonary dysplasia & 2010 \\
\hline NCT01207869 & 1 & Umbilical cord-derived MSCs & Intratracheal & $\begin{array}{c}\text { Infants with bronchopulmonary } \\
\text { dysplasia }\end{array}$ & 2010 \\
\hline NCT01632475 & 1 & $\begin{array}{c}\text { PNEUMOSTEM® (Human } \\
\text { umbilical cord blood-derived MSCs) }\end{array}$ & Intratracheal & $\begin{array}{c}\text { Premature infants with } \\
\text { bronchopulmonary dysplasia }\end{array}$ & 2011 \\
\hline $\begin{array}{c}\text { NCT01297205 } \\
{[126]}\end{array}$ & Completed & $\begin{array}{c}\text { PNEUMOSTEM@ (Human } \\
\text { umbilical cord blood-derived MSCs) }\end{array}$ & Intratracheal & $\begin{array}{c}\text { Premature infants with } \\
\text { bronchopulmonary dysplasia }\end{array}$ & 2011 \\
\hline NCT02023788 & 1 & $\begin{array}{c}\text { PNEUMOSTEM® (Human } \\
\text { umbilical cord blood-derived MSCs) }\end{array}$ & Intratracheal & $\begin{array}{c}\text { Premature infants with } \\
\text { bronchopulmonary dysplasia }\end{array}$ & 2014 \\
\hline NCT01897987 & 2 & $\begin{array}{c}\text { PNEUMOSTEM@ (Human } \\
\text { umbilical cord blood-derived MSCs) }\end{array}$ & Intratracheal & $\begin{array}{c}\text { Premature infants with } \\
\text { bronchopulmonary dysplasia }\end{array}$ & 2014 \\
\hline NCT01828957 & 2 & $\begin{array}{c}\text { PNEUMOSTEM@ (Human } \\
\text { umbilical cord blood-derived MSCs) }\end{array}$ & Intratracheal & $\begin{array}{c}\text { Premature infants with } \\
\text { bronchopulmonary dysplasia }\end{array}$ & 2013 \\
\hline NCT02381366 & 2 & $\begin{array}{c}\text { PNEUMOSTEM® (Human } \\
\text { umbilical cord blood-derived MSCs) }\end{array}$ & - & $\begin{array}{c}\text { Premature infants with } \\
\text { bronchopulmonary dysplasia }\end{array}$ & 2015 \\
\hline NCT01758055 & 1 & MSCs & $\begin{array}{l}\text { Intra-bronchial } \\
\text { injection }\end{array}$ & Pulmonary emphysema & 2012 \\
\hline NCT02013700 & 1 & Human MSCs & $\begin{array}{l}\text { Allogeneic } \\
\text { peripheral } \\
\text { intravenous } \\
\text { infusion } \\
\end{array}$ & Idiopathic pulmonary fibrosis & 2013 \\
\hline $\begin{array}{c}\text { NCT01902082 } \\
{[110]}\end{array}$ & 1 & Adipose-derived MSCs & $\begin{array}{c}\text { Intravenous } \\
\text { infusion }\end{array}$ & ARDS & 2013 \\
\hline NCT01919827 & 1 & Bone marrow-derived MSCs & $\begin{array}{l}\text { Autologous } \\
\text { endobronchial } \\
\text { infusion }\end{array}$ & Idiopathic pulmonary fibrosis & 2013 \\
\hline NCT02045745 & 2 & MSCs & $\begin{array}{l}\text { Directly into } \\
\text { the lung suture line }\end{array}$ & $\begin{array}{l}\text { Patients at risk of post- } \\
\text { operative air leaks } \\
\text { after lung resection }\end{array}$ & 2013 \\
\hline NCT02594839 & 2 & Bone marrow-derived MSCs & $\begin{array}{l}\text { Intravenous } \\
\text { infusion }\end{array}$ & $\begin{array}{c}\text { Idiopathic interstitial } \\
\text { pneumonia associated with } \\
\text { interstitial lung disease }\end{array}$ & 2013 \\
\hline NCT01849159 & 2 & MSCs & $\begin{array}{l}\text { Intravenous } \\
\text { infusion }\end{array}$ & Pulmonary emphysema & 2014 \\
\hline $\begin{array}{c}\text { NCT01775774 } \\
{[127]} \\
\end{array}$ & 2 & Bone marrow-derived human MSCs & $\begin{array}{c}\text { Intravenous } \\
\text { infusion }\end{array}$ & ARDS & \\
\hline NCT02097641 & 2 & Bone marrow-derived human MSCs & $\begin{array}{l}\text { Intravenous } \\
\text { infusion }\end{array}$ & ARDS & 2014 \\
\hline NCT02181712 & 1 & MSCs & $\begin{array}{l}\text { Intravenous } \\
\text { infusion }\end{array}$ & $\begin{array}{l}\text { Lung transplant reject patients } \\
\text { with bronchiolitis obliterans }\end{array}$ & 2014 \\
\hline NCT02135380 & 2 & Adipose-derived MSCs & $\begin{array}{l}\text { Intravenous } \\
\text { infusion }\end{array}$ & Idiopathic pulmonary fibrosis & 2014 \\
\hline NCT02112500 & 2 & Bone marrow-derived MSCs & $\begin{array}{l}\text { Intravenous } \\
\text { infusion }\end{array}$ & ARDS & 2014 \\
\hline NCT02192736 & 2 & Umbilical cord-derived MSCs & Intranasal & Asthma & 2014 \\
\hline NCT02543073 & 2 & MSCs & - & $\begin{array}{l}\text { Interstitial lung disease after } \\
\text { Allo-HSCT }\end{array}$ & 2014 \\
\hline NCT02277145 & 1 & Umbilical cord blood-derived MSCs & $\begin{array}{c}\text { Injection via } \\
\text { fiberoptic } \\
\text { bronchoscopy after } \\
\text { fully lavage of the } \\
\text { localized lesions }\end{array}$ & $\begin{array}{l}\text { Post- } \\
\text { radiotherapy pulmonary fibrosis }\end{array}$ & 2014 \\
\hline NCT02668068 & 1 & Umbilical cord-derived MSCs & $\begin{array}{c}\text { Large volume } \\
\text { whole-lung lavage }\end{array}$ & Pneumoconiosis & 2016 \\
\hline \multirow{2}{*}{ NCT02444455 } & 1 & \multirow{2}{*}{ Umbilical cord-derived MSCs } & \multirow{2}{*}{$\begin{array}{l}\text { Intravenous } \\
\text { infusion }\end{array}$} & ALI & \multirow{2}{*}{2015} \\
\hline & 2 & & & ARDS & \\
\hline
\end{tabular}




\begin{tabular}{|c|c|c|c|c|c|}
\hline NCT02444858 & 2 & Umbilical cord-derived MSCs & $\begin{array}{c}\text { Intravenous } \\
\text { injection }\end{array}$ & $\begin{array}{c}\text { Paraquat poisoning } \\
\text { lung injury }\end{array}$ & 2015 \\
\hline NCT02749448 & 1 & Adipose-derived MSCs & $\begin{array}{c}\text { Intravenous } \\
\text { injection }\end{array}$ & $\begin{array}{c}\text { Airway injury patients that } \\
\text { exposed to sulphur mustard }\end{array}$ & 2015 \\
\hline NCT02625246 & 1 & Bone marrow-derived human MSCs & $\begin{array}{c}\text { Peripheral } \\
\text { intravenous } \\
\text { infusion }\end{array}$ & Bronchiectasis & 2015 \\
\hline NCT02443961 & 1 & MSCs & - & $\begin{array}{c}\text { Premature infants with } \\
\text { bronchopulmonary dysplasia }\end{array}$ & 2015 \\
\hline NCT02645305 & 2 & Adipose-derived MSCs & $\begin{array}{c}\text { Autologous } \\
\text { transfusion }\end{array}$ & COPD & 2015 \\
\hline
\end{tabular}

